\title{
Correlation Coefficient Analysis for Yield and its Components in Sesame (Sesamum indicum L.)
}

\author{
Satankar Navneet*, R.S. Sikarwar and V.S. Kandalkar
}

Department of Genetics and Plant Breeding, College of Agriculture, Gwalior, Rajmata

Vijayaraje Scindia Krishi Vishva Vidyalaya, Gwalior, M.P. 474002, India

*Corresponding author

\begin{tabular}{|l|}
\hline K e y w o r d s \\
Correlation \\
coefficient analysis, \\
Sesamum indicum \\
L. \\
\hline Article Info \\
\hline $\begin{array}{l}\text { Accepted: } \\
\text { 04 June } 2019 \\
\text { Available Online: } \\
\text { 10 July } 2019\end{array}$ \\
\hline
\end{tabular}

An experiment was conducted at Research Farm, RVSKVV, College of Agriculture, Gwalior (M. P.). In kharif season 2015 eight parents and $28 F_{1}$ hybrids were grown in RBD with 3 replications for evaluation of yield and yield attributing traits. Five plants from each parent and hybrid were selected randomly for collection of data of different yield contributing characters such as days to peak flowering, days to maturity, plant height, number of primary branches per plant, number of capsules on main axis, total number of capsules per plant, number of seeds per capsule, capsule length, 1000 seed weight and seed yield per plant. The characters number of primary branches per plant, number of capsules on main axis, total number of capsules per plant and 1000 seed weight showed highly significant positive association with seed yield per plant in for both the generations whereas, number of seeds per capsule and capsule length exhibited significant positive correlation with seed yield per plant in $\mathrm{F}_{1}$ hybrids only. Days to peak flowering and days to maturity showed significantly negative correlation with seed yield per plant for parental population only. According to this study it could be concluded that total number of capsules per plant, number of capsules on main axis, number of primary branches per plant and 1000 seed weight for improvement in yield and days to peak flowering and days to maturity for earliness are promising good selection criteria in sesame.

\section{Introduction}

Sesame (Sesamum indicum L.) is an important oilseed crop belongs to the family Pedaliaceae and it is diploid $(2 \mathrm{n}=26)$ in nature. It is cultivated in around 60-65 countries of the world, while Asian and African countries are the major producers. Asia is rich in diversity of cultivated types while Africa is prosperous in wild varieties. Due to the presence of diverse wild species "Ethiopia" (Africa) is considered as the primary centre of origin, while India and Japan are considered as the two secondary centres of origin of this crop. Sesame is diploid $(2 n=26)$ in nature and is commonly known as Til, Tilli, Gingelly, Ellu, Sim-sim, Benni Seed, Nurvulu, Vellvor Rasi and sesame in different part of the India and often referred as the epithet "the queen of oilseeds". Generally the oil content in sesame ranges from 34 to 63 per cent (Sharma et al., 2014). 
Yield is a very complex character and improvement in this character is not possible by selecting for yield alone, correlation coefficient is very helpful to know the relationship of yield with other character and relationship among the characters which played their role to increase yield. Hence, the present investigation was carried out to get information on character association in 8 parents and 28 hybrids of sesame for ten characters.

\section{Materials and Methods}

Experiment was conducted at Research Farm, RVSKVV, College of Agriculture, Gwalior (M. P.). In kharif season 2014 eight parents were grown (received from College of Agriculture, Tikamgarh JNKVV Jabalpur, Madhya Pradesh) for making half diallel crosses [n (n-1)/2] among them and then next year in kharif season 2015 eight parents and $28 \mathrm{~F}_{1}$ hybrids were grown in RBD with 3 replications for evaluation of yield and yield attributing traits. Five plants from each parent and hybrid were selected randomly for collection of data of different yield contributing characters such as days to peak flowering, days to maturity, plant height, number of primary branches per plant, number of capsules on main axis, total number of capsules per plant, number of seeds per capsule, capsule length, 1000 seed weight and seed yield per plant. Genotypic and phenotypic correlation coefficients were worked out between characters as suggested by Al-Jibouri et al., (1958). Cultural practices were conducted during the growing season according to the recommended package of technology.

\section{Results and Discussion}

Estimation of genotypic and phenotypic correlation coefficient between pairs of seventeen characters in 8 parents and $28 \mathrm{~F}_{1}$ generation of sesame are presented in table 1.
In general the estimates of genotypic and phenotypic correlations were in agreement both in sign and magnitude, but the former were slightly higher than latter.

\section{Correlation between seed yield per plant and other characters}

The characters number of primary branches per plant, number of capsules on main axis, total number of capsules per plant and 1000 seed weight showed highly significant positive association with seed yield per plant in for both the generations. Khan et al., (2001) also reported highly significant correlation of number of branches per plant, number of capsules per plant and 1000 seed weight.

Teklu et al., (2017) reported significant positive association of number of primary branches per plant whereas, significant negative association of number of capsules per plant with seed yield per hectare. Lalpantluangi and Shah 2018 reported significant positive correlation of capsules per plant with seed yield per plant.

Sikarwar (2002) reported number of branches per plant, number of capsules on main branch, number of capsules on secondary branch, total number of capsules per plant and 1000 seed weight significantly positive correlated with seed yield per plant in parents, hybrids and $\mathrm{F}_{2}$ generations. Significantly negative correlation with seed yield per plant was found with days to peak flowering and days to maturity for parental population. Significant negative correlation of days to $50 \%$ flowering with seed yield per plant was also reported by Yol et al., (2010). Teklu et al., (2017) reported correlation of days to maturity was significant negative with seed yield per hectare. Significant positive correlation of days to maturity with seed yield per plant was also reported by Sikarwar (2002) and Lal et al., (2016). 
Table.1 Genotypic and phenotypic correlation coefficient for yield and its components in sesame genotypes (8 parents \& $28 \mathrm{~F}_{1}$ Hybrids)

\begin{tabular}{|c|c|c|c|c|c|c|c|c|c|c|c|}
\hline \multicolumn{2}{|l|}{ Characters } & \multirow{2}{*}{\begin{tabular}{|c|}
$\begin{array}{c}\text { Days to } \\
\text { peak } \\
\text { flowering }\end{array}$ \\
1.000
\end{tabular}} & \multirow{2}{*}{$\begin{array}{c}\begin{array}{c}\text { Days to } \\
\text { maturity }\end{array} \\
0.7551 * * *\end{array}$} & \multirow{2}{*}{$\begin{array}{c}\begin{array}{c}\text { plant } \\
\text { height } \\
(\mathbf{c m})\end{array} \\
0.2033\end{array}$} & \multirow{2}{*}{$\begin{array}{c}\text { No. of } \\
\text { primary } \\
\text { branches } \\
\text { per plant } \\
-0.162\end{array}$} & \multirow{2}{*}{$\begin{array}{c}\begin{array}{c}\text { No. of } \\
\text { capsules on } \\
\text { main axis }\end{array} \\
-0.7114 * * *\end{array}$} & \multirow{2}{*}{$\begin{array}{c}\begin{array}{c}\text { Total No. } \\
\text { of capsules } \\
\text { per Plant }\end{array} \\
-0.6544 * * *\end{array}$} & \multirow{2}{*}{$\begin{array}{c}\text { No. of seeds } \\
\text { Per Capsule } \\
-0.164\end{array}$} & \multirow{2}{*}{$\begin{array}{c}\begin{array}{c}\text { Capsule } \\
\text { length } \\
(\mathbf{c m})\end{array} \\
-0.690 * * *\end{array}$} & \multirow{2}{*}{$\begin{array}{c}\text { 1000 Seed } \\
\text { Weight (g) } \\
-0.3324\end{array}$} & \multirow{2}{*}{$\begin{array}{c}\text { Seed Yield } \\
\text { Per Plant } \\
\text { (g) } \\
-0.6907 * * *\end{array}$} \\
\hline & $\mathrm{P}$ & & & & & & & & & & \\
\hline & $\mathrm{F}_{1}$ & 1.000 & $0.5754 * * *$ & 0.1492 & -0.1249 & -0.1324 & $-0.2199 *$ & 0.0681 & -0.0269 & -0.1161 & -0.1366 \\
\hline \multirow[t]{2}{*}{ Days to maturity } & $\mathrm{P}$ & 0.8444 & 1.000 & 0.2374 & 0.2676 & $-0.7923 * * *$ & -0.403 & -0.0199 & $-0.5331 * *$ & -0.3247 & $-0.4407^{*}$ \\
\hline & $\mathrm{F}_{1}$ & 0.6356 & 1.000 & $0.2320^{*}$ & 0.1247 & -0.0621 & -0.1339 & 0.022 & 0.0289 & -0.1659 & -0.1396 \\
\hline \multirow{2}{*}{$\begin{array}{l}\text { plant height } \\
\text { (cm) }\end{array}$} & $\mathrm{P}$ & 0.2111 & 0.2485 & 1.000 & -0.0093 & -0.1502 & -0.0658 & $0.4464^{*}$ & -0.2093 & -0.2529 & -0.1027 \\
\hline & $\mathrm{F}_{1}$ & 0.1516 & 0.2511 & 1.000 & -0.0827 & 0.0445 & -0.0687 & 0.1106 & $-0.2715^{* *}$ & $-0.1877 *$ & -0.1683 \\
\hline \multirow{2}{*}{$\begin{array}{l}\text { No. of primary } \\
\text { branches per } \\
\text { plant }\end{array}$} & $\mathrm{P}$ & -0.1709 & 0.2522 & -0.0375 & 1.000 & -0.0041 & $0.6902 * * *$ & -0.1199 & -0.0214 & 0.3414 & $0.6563 * * *$ \\
\hline & $\mathrm{F}_{1}$ & -0.1729 & 0.1277 & -0.114 & 1.000 & 0.1614 & $0.5625 * * *$ & -0.1136 & 0.0492 & 0.0911 & $0.3678 * * *$ \\
\hline \multirow{2}{*}{$\begin{array}{l}\text { No. of capsules } \\
\text { on main axis }\end{array}$} & $\mathrm{P}$ & -0.7468 & -0.8991 & -0.1772 & 0.0080 & 1.000 & $0.7103 * * *$ & 0.2558 & $0.5416^{* *}$ & 0.189 & $0.6565 * * *$ \\
\hline & $\mathrm{F}_{1}$ & -0.1564 & -0.0673 & 0.0363 & 0.1903 & 1.000 & $0.5842 * * *$ & $0.2020^{*}$ & $0.2382^{*}$ & $0.2124 *$ & $0.5892 * * *$ \\
\hline \multirow{2}{*}{$\begin{array}{l}\text { Total No. of } \\
\text { capsules per } \\
\text { Plant }\end{array}$} & $\mathrm{P}$ & -0.6850 & -0.4891 & -0.0995 & 0.6840 & 0.7327 & 1.000 & 0.1147 & 0.3896 & 0.3851 & $0.9467 * * *$ \\
\hline & $\mathrm{F}_{1}$ & -0.2324 & -0.1563 & -0.0785 & 0.6122 & 0.6082 & 1.000 & 0.1729 & $0.3273 * * *$ & $0.2355^{*}$ & $0.8327 * * *$ \\
\hline \multirow{2}{*}{$\begin{array}{l}\text { No. of seeds Per } \\
\text { Capsule }\end{array}$} & $\mathrm{P}$ & -0.1677 & -0.0187 & 0.4515 & -0.1259 & 0.2680 & 0.1232 & 1.000 & $0.5532 * *$ & $-0.6974 * * *$ & -0.0081 \\
\hline & $\mathrm{F}_{1}$ & 0.0728 & 0.0255 & 0.1126 & -0.1425 & 0.2077 & 0.1773 & 1.000 & $0.2175^{*}$ & $-0.2842 * *$ & $0.3314 * * *$ \\
\hline \multirow{2}{*}{$\begin{array}{l}\text { Capsule length } \\
\text { (cm) }\end{array}$} & $\mathrm{P}$ & -0.7758 & -0.6277 & -0.2542 & -0.1120 & 0.6789 & 0.4094 & 0.6337 & 1.000 & $-0.1726 * * *$ & 0.3457 \\
\hline & $\mathrm{F}_{1}$ & -0.0405 & 0.0239 & -0.2848 & 0.079 & 0.247 & 0.3517 & 0.2262 & 1.000 & 0.1091 & $0.3743 * * *$ \\
\hline \multirow{2}{*}{$\begin{array}{l}1000 \text { Seed } \\
\text { Weight (g) }\end{array}$} & $\mathrm{P}$ & -0.3817 & -0.4102 & -0.2840 & 0.3722 & 0.2215 & 0.4366 & -0.7560 & -0.1880 & 1.000 & $0.6042 * *$ \\
\hline & $\mathrm{F}_{1}$ & -0.1308 & -0.191 & -0.1956 & 0.1419 & 0.237 & 0.2526 & -0.2826 & 0.1234 & 1.000 & $0.5798 * * *$ \\
\hline \multirow{2}{*}{$\begin{array}{l}\text { Seed Yield Per } \\
\text { Plant (g) }\end{array}$} & $\mathrm{P}$ & -0.7397 & -0.5371 & -0.1310 & 0.6625 & 0.6982 & 0.9750 & -0.0063 & 0.3952 & 0.5882 & 1.000 \\
\hline & $\mathrm{F}_{1}$ & -0.1503 & -0.1596 & -0.1774 & 0.4176 & 0.6185 & 0.8466 & 0.3441 & 0.4016 & 0.5723 & 1.000 \\
\hline
\end{tabular}


Number of seeds per capsule and capsule length exhibited significantly positive association with seed yield per plant in $F_{1}$ hybrids only. Similar findings were also reported by Sikarwar (2002), Parmeshwarappa et al., (2009) and Teklu et al., (2017).

\section{Inter correlation among the characters}

The results revealed that the character days to peak flowering exhibited significantly positive association with days to maturity whereas, significantly negative association with total number of capsules per plant in both the generations. This trait showed highly significant and negative association with number of capsules on main axis and capsule length in parental population only. This results in the harmony with Telku et al., (2017) and Lalpantluangi and Shah (2018). Days to maturity showed highly significant and negative association with number of capsules on main axis and capsule length in parental population. For $\mathrm{F}_{1}$ hybrids significant positive correlation was found with plant height only. Telku et al., (2017) also reported days to maturity showed significant positive correlation with plant height and significant negative correlation with capsule length. Number of primary branches per plant showed highly significant and positive correlation with total number of capsules per plant in both the generations. Similar findings have earlier reported by Sikarwar (2002) and Daniya et al., (2013). The trait number of capsules on main axis exhibited significant and positive correlation with total number of capsules per plant and capsule length for both parents and hybrids. Significant positive correlation of this trait was found with number of seeds per capsule and 1000 seed weight for hybrids only. Such trends were also reported by Sikarwar (2002) and Lal et al., (2016). For the character total number of capsules per plant significant positive correlation was found with capsule length and 1000 seed weight in hybrid population whereas, parental population showed positive but non-significant correlation with the same traits. Parmeshwarappa et al., (2009) and Daniya et al., (2013) reported number of capsules per plant significantly and positively correlated with capsule length. Yol et al., 2010 reported significant positive association between number of capsules and 1000 seed weight. Number of seeds per capsule showed significantly positive correlation with capsule length while, significantly negative correlation with 1000 seed weight in both the generations. Significant positive association between capsule length and number of seeds per capsule was also reported by Yol et al., (2010). Vanishree et al., (2011) reported number of seeds per capsule was significantly and positively correlated with 1000 seed weight. Capsule length showed highly significant and negative association with 1000 seed weight in parental population only. Negative association of capsule length with 1000 seed weight were also reported by some workers viz. Lal et al., (2016) and Lalpantluangi and Shah (2018).

The conclusions were drawn from the study of genotypic and phenotypic correlation coefficient; to increase seed yield per plant, selection should be made for total number of capsules per plant, number of capsules on main axis, number of primary branches per plant and 1000 seed weight. Days to peak flowering and days to maturity may be considered as efficient alternate criteria of selection for selecting early maturing genotypes in sesame.

\section{References}

Al-Jibouri, H.A. Miller, P.A. and Robinson, H.F. (1958). Genotypic and environmental covariances in an upland 
cotton cross of inter specific origin. Agron. J.; 50: 633-637.

Daniya, E., Dadari, S. A., Ndahi, W. B., Kuchinda, N. C. and Babaji, B. A. (2013). Correlation and Path Analysis between Seed Yield and some Weed and Quantitative Components in Two Sesame (Sesamum indicum L.) Varieties as influenced by Seed Rate and Nitrogen Fertilizers. Journal of Biology, Agriculture and Healthcare. 3 (15): 1217.

Khan, Noor-ul Islam, Akbar, Muhammad, Sabir, Khalid Mehmood and Iqbal, Shahid (2001). Characters association and path coefficient analysis in sesame (Sesamum indicum L.). Journal of Biological Sciences. 1 (3): 99-100.

Lal, M., Dutta, S., Saikia D., and Bhau, B. S. (2016). Assessment of selection criteria in sesame by using correlation and path coefficient analysis under high moisture and acidic stress soil condition. Indian Journal of Science and Technology. 9(4): 1-5.

Lalpantluangi, PC and Shah, Pankaj (2018). Character association and path coefficient analysis in sesame (Sesamum indicum L.) genotypes under foothill condition of Nagaland. The Pharma Innovation Journal. 7(5): 8287.

Parameshwarappa, S. G., Palakshappa, M. G., Salimath, P. M. and Parameshwarappa, K. G. (2009). Studies on genetic variability and character association in germplasm collection of sesame
(Sesamum indicum L.). Karnataka J. Agric. Sci. 22 (22): 252-254.

Sharma, Ekta Shah, Tajamul Islam and Khan, Fatima (2014). A review enlightening genetic divergence in Sesamum indicum based on morphological and molecular studies. International Journal of Agriculture and Crop Sciences; 7(1):19.

Sikarwar, R. S. (2002). Genetic study in sesame (Sesamum indicum L.). Ph. D. (Plant Breeding \& Genetics) Thesis, Dr. B. R. Ambedkar University, Agra, (U. P.).

Teklu, D. H., Kebede, S. A. and Gebremichael D. E. (2017). Assessment of genetic variability, genetic advance, correlation and path analysis for morphological traits in sesame genotypes. International Journal of Novel Research in Life Sciences. 4 (2): 34-44.

Vanishree, Lokesha, R., Diwan, J.R. and M.V. Ravi (2011). Study on character association and contribution of yield related traits to seed yield in segregating generation ( $\mathrm{F}_{4}$ Families) of Sesame (Sesamum indicum L.). Electronic Journal of Plant Breeding. 2(4):559562.

Yol, E., Emre K., Furat S. and Uzun B. (2010). Assessment of selection criteria in sesame by using correlation coefficients, path and factor analyses. Australian Journal of Crop Science. 4 (8):598-602.

\section{How to cite this article:}

Satankar Navneet, R.S. Sikarwar and Kandalkar, V.S. 2019. Correlation Coefficient Analysis for Yield and its Components in Sesame (Sesamum indicum L.). Int.J.Curr.Microbiol.App.Sci. 8(07): 372-376. doi: https://doi.org/10.20546/ijcmas.2019.807.046 